\title{
Using Moringa olifera Leaf Extract as a Bio-fertilizer for Drought Stress Mitigation of Glycine max L. Plants
}

\author{
Rania S. Hanafy \\ Biological and Geological Sciences Department, Faculty of Education, \\ Ain Shams University, 1575 Cairo, Egypt.
}

ROUGHT is one of a considerable environmental stresses limiting productivity of
crops. This work was conducted to investigate the effect of foliar spray of plant leaf
extract (Moringa olifera) to alleviate drought stress in Glycine maxplants (cv.Giza 111).
Drought caused significant decreases in growth parameters (shoot and root length, fresh and
dry weight of shoots and roots) and photosynthetic pigments (chlorophyll a, chlorophyll b,
carotenoids and total pigments). In addition, it caused significant increasesi n non-enzymatic
antioxidants (ascorbic acid, tocopherol and reduced glutathione), enzymatic antioxidants
(glutathione reductase, superoxide dismutase and ascrobate peroxidase), oxidative damage
(lipid peroxidation) and osmolyte compounds (proline, total soluble sugars and total phenols)
in soybean plants. Moreover, foliar spray with Moringa leaf extract (MLE ${ }_{(30)}$ ) enhanced all the
above parameters as compared with either the control plants and drought stressed plants. It
appeared that MLE
(30)

Keywords: Drought, Moringa olifera, Lipid peroxidation, Antioxidant enzymes, Phytohormones, Minerals.

\section{Introduction}

Droughtis abiotic stress limiting factors of plant growth and yields thus negatively affect production of over $25 \%$ of world agriculture. Deficit of soil water caused significant reduction in photochemical activities in some plants, reduction in the activities of enzymes responsible for some processes like respiration, translocation, hormone balance, macro and micro nutrients uptake and metabolism (Rohbakhsh, 2013). Drought give rise to excessive generation of some reactive oxygen species (ROS) (superoxide anion $\left(\mathrm{O}_{2}{ }^{--}\right)$, hydrogen peroxide $\left(\mathrm{H}_{2} \mathrm{O}_{2}\right)$, hydroxyl radicals $\left(\mathrm{OH}^{\prime}\right)$ and singlet oxygen $\left({ }^{1} \mathrm{O}_{2}\right)$ as a result of the imbalance between the productions of these species and the production of the antioxidant defense system resulting in oxidative damages in plant cells (El-Tayeb, 2006) that represented in lipid peroxidation, chlorophyll bleaching, protein, DNA and RNA damages. On the other hand, plants tend to accumulate some osmoprotectants and antioxidant compounds such as proline, phenols and soluble sugars, as well as formation of scavenging radicals such as glutathione, ascorbate, $\alpha$-tocopherol, flavonoids, carotenoids and some antioxidant enzymes such as glutathione reductase (GR), superoxide dismutase (SOD), ascorbate peroxides (APX) which play a protective role in scavenging ROS free radical species (El-Beltagi \& Mohamed, 2013).

Soybean (Glycine max) is an important economical and nutritious crop plant, it has high contents of protein (40-42\%), oils (18-22\%) and has some secondary metabolic compounds such as phenols, flavonoids and saponins (Sakthivelu et al., 2008). Inorganic fertilizers are good source of plant nutrients but they are high cost. Thus, recent searches need to find alternative safe, effective and natural plant fertilizers. Moringa oleiferatree (Identified as Mother's Best Friend and Miracle Tree.) belongs to Moringaceae. It has great importance due to its parts (root, bark, gum, leaf, flower, fruit, seed and seeds oil) which have incredible effects of food, medication and industrial purposes (Moyo et al., 2011).Moringa oleifera leaves extract (MLE) is the most natural 
plant growth enhancer, has no cost and enhance the tolerance of plants under different environmental conditions like drought. It needs more attentions due to its high contents of proteins, antioxidants (ascorbic acid, flavonoids, phenolics, carotenoids), mineral ions ( $\mathrm{P}, \mathrm{Ca}, \mathrm{Fe}, \mathrm{K}, \mathrm{Cr}, \mathrm{Cu}, \mathrm{Mg}, \mathrm{Mn}$ and $\mathrm{Zn}$ ), amino acids, vitamin $\mathrm{A}$, vitamin $\mathrm{C}$, B- complex and plant hormones especially cytokinins (zeatin) (Azra et al., 2012). Drought stress has destructive effect on the content of cytokinin in plant. On the other hand, the high level of zeatin makes Moringa leaves extract (MLE) more effective as a natural compound promoting plant tolerance under stress conditions (Zaki \& Rady, 2015). Therefore, this work was designed with objective to evaluate the potential effects of the foliar application of aqueous leaves extract of Moringa (MLE) as a bio-organic fertilizer in alleviating the effects of water stress (drought) in Soybean (Glycine max L.) plants.

\section{Material and Methods}

Plant material, cultivation and drought imposition

Healthy Glycine max (cv. Giza 111) seeds were obtained from the Crop Institute, Agriculture Research Center, Ministry of Agriculture, Giza, Egypt. Soybean seeds were washed in distilled water then sterilized using ethanol $(70 \%)$ for 2 min, then sodium hypochlorite $(5 \%)$ ( (v/v) for 10 min followed by rinsed with distilled water several times and left to air dried. Seeds are grown at 23$\mathrm{cm}$ depth in $25 \mathrm{~cm}$ diameter pots containing equal amount of homogeneous loamy clay soil. The pots were arranged into two groups designed with two factors, MLE dilutions (30 times) and soil water levels (well-watered and drought stressed). After 7 weeks from sowing, drought stress (based on soil water holding capacity) was imposed. The irrigation levels were maintained at $80 \%$ (wellwatered), 60\% (moderate drought stressed) and $40 \%$ (severe drought stressed) field capacity. The plants were divided into six groups and treated as follows: Plants of the $1^{\text {st }}$ group were left without any treatment to serve as control (well-watered). The $2^{\text {nd }}$ group was well watered and sprayed with $\mathrm{MLE}_{30}$ extract. The $3^{\text {rd }}$ group was irrigated with $60 \%$ of hold water capacity. The $4^{\text {th }}$ group was irrigated with $60 \%$ of hold water capacity and sprayed with $\mathrm{MLE}_{30}$ extract. The $5^{\text {th }}$ group was irrigated with $40 \%$ of hold water capacity. The $6^{\text {th }}$ group was irrigated with $40 \%$ of hold water capacity and sprayed with $\mathrm{MLE}_{30}$ extract. The foliar application with MLE extract was carried out twice at the age of 7 and 10 weeks $(20 \mathrm{ml} /$ plant). After 14 weeks from sowing, five plants were collected to determine growth parameters (shoot length, root length, fresh and dry weights of shoots and roots), photosynthetic pigments, non-enzymatic antioxidants (tocopherol (vitamin E), ascorbic acid (vitamin C) and glutathione), lipid peroxidation, enzymatic antioxidant (glutathione reductase, superoxide dismutase and ascorbate peroxides), soluble sugars, proline, total phenols, phytohormones (IAA, $\mathrm{GA}_{3}$ and $\mathrm{ABA}$ ) and minerals in plant leaves.

\section{Preparation and analysis of MLE extract}

MLE was prepared according to procedures described by Azra et al. (2012). Moringa oleifera leaves were collected from the botanical garden of Faculty of Education, Ain Shams University. Leaves after storing in freezing temperature overnight were ground in water $(1 / 10 \mathrm{wt} / \mathrm{v})$. The mixture was shaken for $4 \mathrm{~h}$ using electrical stirrer, and then left in dark for $28 \mathrm{~h}$ at room temperature. The mixture was filtered using cheesecloth and the filtrate centrifuged at $8000 \mathrm{~g}$ for $15 \mathrm{~min}$ and diluted 30 times by using distilled water.

\section{Biochemical analysis \\ Determination of photosynthetic pigments}

Chlorophyll a,b and carotenoids were estimated by spectrophotometric method recommended by Lichtenthaler (1987) with Spekol spectrophotometer VEB Carl Zeiss at the recommended lengths. The pigments content were calculated as $\mathrm{mg} \mathrm{g}^{-1}$ fresh weight of leaves.

\section{Changes in non-enzymatic antioxidant}

Determination of ascorbic acid (ASA) (vitamin $C$ ): ASA was estimated as detected by Mukherjee \& Choudhuri (1983). The content was expressed in $\mu \mathrm{g} \mathrm{g}^{-1}$ fresh weight. A sample of fresh weight leaves $(2 \mathrm{~g})$ was homogonized using trichloroacetic acid (TCA) (6\%). After filtration of the extract, it was centrifuged at $1000 \mathrm{~g}$ for 20 min. and then the filtrate was adjusted to $10 \mathrm{ml}$ with TCA. Four $\mathrm{ml}$ of the extract was added to $2 \mathrm{ml}$ of acidic $2 \%$ dinitrophenyl hydrazine and few drops of $10 \%$ thiourea (in $70 \%$ ethanol). The mixture was boiled in a water bath for $15 \mathrm{~min}$ followed by cooling at room temperature, $5 \mathrm{ml}$ of $80 \% \mathrm{H}_{2} \mathrm{SO}_{4}(\mathrm{v} / \mathrm{v})$ was added to the mixture in an ice bath; the obtained color was measured at 530 $\mathrm{nm}$. The amount of ascorbic acid was calculated and expressed as $\mathrm{mg} \mathrm{g}^{-1}$ fresh weight.

Determination of $\alpha$-tocopherol (vitamin E):

$\alpha$-tocopherol content was measured according to the method described by Philip et al. (1954). Five grams of fresh leaves was homogenized in 
$10 \mathrm{ml}$ of a solution consists of petroleum ether and ethanol $(2: 1.6 \mathrm{v} / \mathrm{v})$. The extract was centrifuged at $10,000 \mathrm{~g}$ for $20 \mathrm{~min}$. One $\mathrm{ml}$ of extract was mixed with $0.2 \mathrm{ml}$ of $2 \%$ 2.2-dipyridyl in ethanol and kept in the dark for $5 \mathrm{~min}$. The resulting color (red color) was diluted with $4 \mathrm{ml}$ of distilled water, then measured at $520 \mathrm{~nm}$. The $\alpha$-tocopherol contents were calculated against a known standard curve using several concentrations of $\alpha$-tocopherols. The content was expressed as $\mu \mathrm{g} / \mathrm{g}$ fresh weight.

Determination of reduced glutathione contents:The total non-protein $\mathrm{SH}$ group GSH (reduced glutathione) was estimated following the method of Paradiso et al. (2008). One gram plant sample was ground with $6 \%$ meta-phosphoric acid (w/v) and $1 \mathrm{mM}$ EDTA. The homogenate was centrifuged at $11.500 \mathrm{~g}$ for $15 \mathrm{~min}$ at $4^{\circ} \mathrm{C}$. Then, 0.4 $\mathrm{ml}$ of supernatant and $0.5 \mathrm{M}$ potassium phosphate buffer ( $\mathrm{pH} 7.5$ ) were added. This was incubated in an assay mixture containing $10 \mathrm{mM}$ BSA, $10 \mathrm{mM}$ 5,5'-dithio-bis (2 nitrobenzoic acid) (DTNB), 0.5 $\mathrm{mM} \mathrm{NADH}$ at $37^{\circ} \mathrm{C}$ for $15 \mathrm{~min}$. Absorbance was read at $412 \mathrm{~nm}$. Oxidized glutathione (GSSG) was assayed in the same mixture but with addition of 2-vinyl pyrrolidine for reduced glutathione (GSH) removal and reacted in the same way as reported by $\mathrm{Yu}$ et al. (2003). For standard preparation synthetically glutathione, reduced (GSH) and oxidized (GSSG) was used.

\section{Assay of antioxidant enzymes activities}

The samples $(0.3 \mathrm{~g})$ were grinded in $5.0 \mathrm{ml}$ sodium phosphate buffer ( $\mathrm{pH} 7.8$ ). After filtration, the sample was centrifuged at $10.000 \mathrm{~g}$ for $20 \mathrm{~min}$ and the obtained supernatant was used for GR, SOD and APX activities. Glutathione reductase (GR) activity was determined as the rate of NADPH oxidation according to Schaedle \& Bassham (1977). The absorbance was measured at $340 \mathrm{~nm}$.Superoxide dismutase:SOD (EC 1.12.1.1) activity was assayed by inhibition of nitroblue tetrazolium chloride (NBT) as described by Chen \& Wang (2006). Absorbance was read at 560 nm. Ascorbate peroxidase: APX(EC 1.11.1.11) activity was determined according to the method of Nakano \& Asada (1987). The hydrogen peroxide was determined by the decrease in absorbance of ascorbate at $290 \mathrm{~nm}$.

\section{Determination of malondialdehyde (MDA)} content

Lipid peroxidation was determined based on MDA content and measured according to the method of Heath \& Packer (1968). $0.5 \mathrm{~g}$ fresh leaves were ground in $10 \mathrm{ml}$ of $6 \%$ trichloroacetic acid (TCA) and centrifuged at $10.000 \mathrm{~g}$ for 15 min. $1 \mathrm{ml}$ of the supernatant and $4 \mathrm{ml}$ of $0.5 \%$ thiobarbitric acid were mixed well at $95^{\circ} \mathrm{C}$ for $30 \mathrm{~min}$. Non-specific absorbance at $600 \mathrm{~nm}$ was subtracted from the $532 \mathrm{~nm}$ absorbance. The content of MDA was calculated by using the coefficient of $155 \mathrm{~m} / \mathrm{M} / \mathrm{cm}$ and expressed as $\mathrm{nmol} \mathrm{MDA} / \mathrm{g}$ fresh weight.

\section{Determination of soluble sugars}

A known weight of dry leaves (1g) was submerged in $10 \mathrm{ml}$ of $80 \%(\mathrm{v} / \mathrm{v})$ ethanol at $25^{\circ} \mathrm{C}$ overnight with shaking, and centrifuged at $6000 \mathrm{~g}$. Ethanol in the supernatant was then evaporated completely and dissolved in a known volume of distilled water to determine soluble carbohydrates (Homme et al., 1992). Total soluble sugars (TSS) were detected by reacting $0.1 \mathrm{ml}$ of ethanolic extract with $3.0 \mathrm{ml}$ anthrone (freshly prepared) $(150 \mathrm{mg}$ anthrone $+100 \mathrm{ml}$ $72 \% \mathrm{H}_{2} \mathrm{SO}_{4}$ ) in boiling water bath for $10 \mathrm{~min}$ and reading the cooled samples (cooled at room temperature) at 625 using glucose standard for calibration. The soluble sugars in the sample were expressed as mg glucose/g dry weight.

\section{Assay of free proline content}

Proline content was determined using the method of Bates et al. (1973). One gram fresh leaves of soybean plants were homogenized in aqueous sulfo-salicylic acid (3\%). The extract was filtered. Then the glacial acetic acid and ninhydrin solution at $100^{\circ} \mathrm{C}$ for $1 \mathrm{~h}$ followed by terminating in ice bath and mixed with toluene. The toluene phase was aspirated from the aqueous phase. The contents were determined colorimetric at $520 \mathrm{~nm}$ and calculated as $\mu \mathrm{M} \mathrm{g}^{-1}$ fresh weight.

\section{Determination of total phenolic contents (TPC)}

One gram of frozen leaves was ground in 50 $\mathrm{ml}$ of methanol. The homogenate was shaken for $1 \mathrm{~h}$ at room temperature. Then the extract was filtered. The concentration of total phenols was detected according to Kim et al. (2003) using tannic acid as a standard. $1 \mathrm{ml}$ of extract, deionized water $(10 \mathrm{ml})$ and $1 \mathrm{ml}$ of $10 \%$ FolinCiocalteu phenol were added. Five min later, sodium carbonate solution $20 \%(2.0 \mathrm{ml})$ was added. Then solution was kept in darkness, the absorbance was measured at $750 \mathrm{~nm}$ and expressed as mg tannic acid $\mathrm{g}^{-1}$ dry weight.

Determination of phytohormones

Extraction and estimation of endogenous 
phytohormones were carried out following the method of Ünyayar et al. (1996). The frozen leaves were ground in cold $80 \%$ methanol, then, triple extraction with methanol at $0{ }^{\circ} \mathrm{C}$ for $2 \mathrm{~h}$ was occur. Analysis of acidic hormones, indole acetic acid (IAA), gibberellic acid $\left(\mathrm{GA}_{3}\right)$ and abscisic acid (ABA) were analyzed using GLC (Varien Vesta, 6000).

\section{Determination of Minerals}

Nitrogen $(\mathrm{N})$ was determined in dried leaf tissues by using micro-Kjeldahl method after digestion in sulphuric acid according to Yemm \& Willis (1956). Phosphorus (P) was determined according to the method described by Humphries (1956) by using molybdenum blue method. The total contents of cation $(\mathrm{K})$ in dried leaf tissues were estimated after digestion method using perchloric acid $\left(\mathrm{HClO}_{4}\right)$, nitric acid $\left(\mathrm{HNO}_{3}\right)$ in a Kjeldahl digestion apparatus (AOAC, 1995). K content was measured by using flame photometer.

\section{Statistical analysis}

Results of all parameters were statistically analyzed by using ANOVA test and the mean differences were compared by the Duncan test at $5 \%$ significance level.

\section{Results}

As shown in Table 1 it shows some chemical composition of Moringa leaf extract. It was found that $\mathrm{MLE}_{(30)}$ is rich in some nutrients, some antioxidants such as ascorbic acid, $\alpha$ - tochopherol, phenols, flavonoids, as well as phytohormones like indol acidic acid and gibberellins. Results presented in Table 2, showed that, plant growth parameters (shoot and root length, fresh and dry weights of shoots and roots) of drought stressed Glycine max plants were affected. Data showed that the effect of drought on soybean plant increased according to decreased water hold capacity ( $60 \%$ and $40 \%$ hold water capacity). It was decreased significantly with increasing drought stress as compared with control plants. Further, spraying Moringa oleifera leaf extract $\left(\mathrm{MLE}_{30}\right)$ alone caused a noticeable improvement in all of mentioned growth parameters compared to untreated plants, indicating the higher efficiency of growth, development in the presence of $\left(\mathrm{MLE}_{30}\right)$ supplementation. On the other hand, combined $\mathrm{MLE}_{(30)}$ application with drought stress showed highly significant increases in growth traits as compared with either drought stressed plants or well-watered plants.Photosynthetic pigment (chlorophyll a, b and total pigments) contents in leaves of soybean plants were significantly decreased gradually with increasing level of drought stress. Data in Table 3 clearly showed that, spraying with $\mathrm{MLE}_{(30)}$ alone alleviates the drought stress and caused significant increase in pigment contents (chlorophyll a, chlorophyll $\mathrm{b}$ and consequently total pigments) as compared with control. Data in the same table also show that, foliar spraying of soybean plants with Moringa oleifera leaf extract $\left(\mathrm{MLE}_{30}\right)$ caused significant increases in chlorophyll a, b, carotenoids and consequently total pigments as compared with control and the corresponding drought levels $(60 \%$ and $40 \%$ hold water capacity).

It is evident that drought stress caused a noticeable increase in ascorbic acid, $\alpha$-tocopherol and glutathione contents in leaves of soybean plants with increasing drought levels as compared with control plants (Table 4). In addition, spraying plants with Moringa oleifera leaf $\left(\mathrm{MLE}_{30}\right)$ extract, gave significant enhancement in ascorbic acid, $\alpha$-tocopherol and GSH contents of leaves of treated soybean plants above that of the corresponding controls. Pronounced increases in antioxidant compounds was observed under foliar spraying of drought stressed soybean plants with $\mathrm{MLE}_{30}$ as compared with control plants and the corresponding drought levels $(60 \%$ and $40 \%$ hold water capacity).

Changes in the activity of antioxidant enzymes were correlated with oxidative stress. The effect of drought stress levels on GR, SOD and APX activities in leaves of soybean cv. 111 plant either without or with $\mathrm{MLE}_{30}$ treatment was assayed. As shown in Table 5, increasing drought stress resulted in considerable increases in the activities of GR, SOD and APX enzymes of stressed plants as compared with those of control plants. The maximum activity of the antioxidant enzymes was observed in SOD enzyme. SOD was displayed at the highest level of drought as compared with the unstressed control plants. Spraying of $\mathrm{MLE}_{30}$ alone or combined with drought stress caused high significant increase in SOD activity in the leaves of plants as compared with control. The same trends for GR and APX activities in the presence and absence of $\mathrm{MLE}_{30}$ in drought stressed plants were obtained as similar to those for SOD. Under drought stress, MDA content increased in soybean plants as compared with the control plants (Table 6). In contrast, foliar spray with $\mathrm{MLE}_{30}$ reduced the MDA levels by $89 \%$ and $84 \%$ with drought levels (60\% and $40 \%$ hold water capacity, respectively) as compared with drought stressed plants. 
TABLE 1. Some chemical components of Moringa oleifera leaf extract (dry weight basis).

\begin{tabular}{|c|c|c|c|}
\hline \multicolumn{4}{|c|}{$\begin{array}{c}\text { Chemical components } \\
\left(\mathrm{mg} \mathrm{g}^{-1} \mathrm{DW}\right)\end{array}$} \\
\hline Calcium & 5.17 & Ascorbic acid (vitamin C) & 5.3 \\
\hline Magnesium & 4.85 & Tochopherol (vitamin E) & 113 \\
\hline Phosphorus & 4.08 & Total phenols & 3.36 \\
\hline Potassium & 25.5 & Total flavonoids & 7.12 \\
\hline Copper & 0.38 & IAA & 0.746 \\
\hline Iron & 2.4 & $\mathrm{GA}_{3}$ & 0.602 \\
\hline Total amino acids & 210.5 & $\mathrm{ABA}$ & 0.176 \\
\hline
\end{tabular}

TABLE 2. Effects of foliar spraying of $\mathrm{MLE}_{(30)}$ on growth parameters in Glycine max (cv. Giza 111) plants grown under drought stress conditions.

\begin{tabular}{|c|c|c|c|c|c|c|}
\hline Treatments & $\begin{array}{c}\text { Shoot } \\
\text { length } \\
(\mathrm{cm})\end{array}$ & $\begin{array}{c}\text { Root } \\
\text { length } \\
(\mathrm{cm})\end{array}$ & $\begin{array}{l}\text { Fresh wt. } \\
\text { of shoots } \\
\text { (g) }\end{array}$ & $\begin{array}{l}\text { Dry wt. of } \\
\text { shoots } \\
\text { (g) }\end{array}$ & $\begin{array}{l}\text { Fresh wt. } \\
\text { of roots } \\
\text { (g) }\end{array}$ & $\begin{array}{l}\text { Dry wt. } \\
\text { of roots } \\
\quad \text { (g) }\end{array}$ \\
\hline Control & $45.3^{\mathrm{d}}$ & $31.4^{\mathrm{b}}$ & $5.6^{\mathrm{c}}$ & $1.5^{\mathrm{b}}$ & $1.8^{\mathrm{ab}}$ & $0.35^{\mathrm{b}}$ \\
\hline MLE (30) & $52.0^{\mathrm{b}}$ & $32.2^{\mathrm{ab}}$ & $6.5^{b}$ & $1.8^{\mathrm{b}}$ & $1.9^{\mathrm{ab}}$ & $0.45^{\mathrm{a}}$ \\
\hline Hold water capacity $60 \%$ & $39.6^{\mathrm{e}}$ & $27.7^{\mathrm{c}}$ & $5.3^{\mathrm{c}}$ & $1.3^{\mathrm{c}}$ & $1.6^{\mathrm{bc}}$ & $0.32^{\mathrm{b}}$ \\
\hline Hold water capacity $60 \%+\operatorname{MLE}_{(30)}$ & $56.2^{\mathrm{a}}$ & $33.5^{\mathrm{a}}$ & $7.2^{\mathrm{a}}$ & $1.9^{\mathrm{a}}$ & $2.1^{\mathrm{a}}$ & $0.41^{\mathrm{a}}$ \\
\hline Hold water capacity $40 \%$ & $32.4^{\mathrm{f}}$ & $26.3^{\mathrm{c}}$ & $4.8^{\mathrm{d}}$ & $1.1^{\mathrm{c}}$ & $1.2^{\mathrm{c}}$ & $0.28^{\mathrm{b}}$ \\
\hline Hold water capacity $40 \%+\mathrm{MLE}_{(30)}$ & $50.3^{c}$ & $33.3^{\mathrm{ab}}$ & $6.1^{\mathrm{b}}$ & $1.6^{\mathrm{b}}$ & $1.9^{\mathrm{ab}}$ & $0.35^{b}$ \\
\hline
\end{tabular}

Means with the same letters are not significantly different at $\mathrm{P} \leq 0.05$ by Duncan's multiple range test.

TABLE 3. Effects of foliar spraying of MLE ${ }_{(30)}$ on photosynthetic pigment content (mg/g) in Glycine max (cv. Giza 111) plants grown under drought stress conditions.

\begin{tabular}{|c|c|c|c|c|}
\hline Treatments & $\begin{array}{c}\text { Chl a } \\
\mathrm{mg} \mathrm{g}^{-1} \mathrm{FW}\end{array}$ & $\begin{array}{c}\text { Chl b } \\
\mathrm{mg} \mathrm{g}^{-1} \text { FW } \\
\end{array}$ & $\begin{array}{c}\text { Carotenoids } \\
\text { mg g }^{-1} \text { FW }\end{array}$ & $\begin{array}{l}\text { Total pigments } \\
\text { mg g }^{-1} \mathbf{F W}\end{array}$ \\
\hline Control & $8.21^{\mathrm{c}}$ & $3.32^{\mathrm{b}}$ & $2.72^{\mathrm{ab}}$ & $14.25^{\mathrm{d}}$ \\
\hline $\operatorname{MLE}_{(30)}$ & $9.25^{b}$ & $3.56^{\mathrm{b}}$ & $2.44^{\mathrm{ab}}$ & $15.25^{\mathrm{c}}$ \\
\hline Hold water capacity $60 \%$ & $7.10^{\mathrm{d}}$ & $2.79^{\mathrm{c}}$ & $2.49^{\mathrm{ab}}$ & $12.13^{\mathrm{c}}$ \\
\hline Hold water capacity $60 \%+\mathrm{MLE}_{(30)}$ & $10.0^{2 \mathrm{a}}$ & $4.47^{\mathrm{a}}$ & $2.99^{a}$ & $17.51^{\mathrm{a}}$ \\
\hline Hold water capacity $40 \%$ & $5.29^{e}$ & $2.22^{\mathrm{d}}$ & $2.05^{b}$ & $9.56^{\mathrm{f}}$ \\
\hline Hold water capacity $40 \%+\mathrm{MLE}_{(30)}$ & $9.60^{\mathrm{b}}$ & $3.53^{\mathrm{b}}$ & $2.88^{a}$ & $16.01^{\mathrm{b}}$ \\
\hline
\end{tabular}


TABLE 4. Effect of foliar spraying of $M_{(30)}$ on non-enzymatic antioxidants in Glycine max (cv. Giza 111) plants grown under drought stress conditions

\begin{tabular}{|c|c|c|c|}
\hline Treatments & $\begin{array}{l}\text { Ascorbic acid } \\
\mu \mathrm{mol} \mathrm{g}^{-1} \mathrm{FW}\end{array}$ & $\begin{array}{c}\alpha \text {-tocopherol } \\
\mu \mathrm{g} \mathrm{g}^{-1} \mathrm{FW}\end{array}$ & $\begin{array}{c}\text { Reduced glutathione } \\
\left(\text { GSH) } \mu \mathrm{mol} \mathrm{g}^{-1} \mathrm{FW}\right. \\
\mu \mathrm{mol} \mathrm{g} \mathrm{g}^{-1} \mathrm{FW} \\
\end{array}$ \\
\hline Control & $40.96^{\mathrm{e}}$ & $27.12^{\mathrm{d}}$ & $13.69^{\mathrm{d}}$ \\
\hline $\operatorname{MLE}_{(30)}$ & $44.65^{d}$ & $43.31^{\mathrm{c}}$ & $14.99_{\mathrm{d}}$ \\
\hline Hold water capacity $60 \%$ & $48.43^{\mathrm{c}}$ & $44.11^{\mathrm{c}}$ & $25.96^{\mathrm{c}}$ \\
\hline Hold water capacity $60 \%+$ MLE $_{(30)}$ & $49.55^{\text {bc }}$ & $52.99^{\mathrm{b}}$ & $29.40^{\mathrm{b}}$ \\
\hline Hold water capacity $40 \%$ & $51.24^{\mathrm{ab}}$ & $55.21^{\mathrm{ab}}$ & $31.88^{\mathrm{b}}$ \\
\hline Hold water capacity $40 \%+$ MLE $_{(30)}$ & $53.33^{\mathrm{a}}$ & $55.99^{\text {a }}$ & $35.37^{\mathrm{a}}$ \\
\hline
\end{tabular}

Means with the same letters are not significantly different at $\mathrm{P} \leq 0.05$ by Duncan's multiple range test.

TABLE 5. Effect of foliar spraying of MLE ${ }_{(30)}$ on enzymatic antioxidants in in Glycine max (cv. Giza 111) plants grown under drought stress conditions.

\begin{tabular}{|c|c|c|c|}
\hline Treatments & $\begin{array}{c}\text { Glutathione } \\
\text { reductase (GR) } \\
\left.\text { (unit } \text { min }^{-1} \mathrm{~g}^{-1} \mathrm{FW}\right)\end{array}$ & $\begin{array}{c}\text { Superoxide } \\
\text { dismutase (SOD) } \\
\left.\text { (unit } \text { min }^{-1} \mathrm{~g}^{-1} \mathrm{FW}\right)\end{array}$ & $\begin{array}{c}\text { Ascorbate } \\
\text { peroxidase (APX) } \\
\left(\text { unit } \text { min }^{-1} \mathrm{~g}^{-1} \mathrm{FW}\right)\end{array}$ \\
\hline Control & $0.606^{\mathrm{a}}$ & $24.37^{\mathrm{d}}$ & $0.318^{\mathrm{d}}$ \\
\hline $\operatorname{MLE}_{(30)}$ & $0.616^{\mathrm{a}}$ & $29.16^{\mathrm{c}}$ & $0.375^{d}$ \\
\hline Hold water capacity $60 \%$ & $0.631^{\mathrm{a}}$ & $32.22^{b}$ & $0.388^{\mathrm{d}}$ \\
\hline Hold water capacity $60 \%+\mathrm{MLE}_{(30)}$ & $0.634^{\mathrm{a}}$ & $34.69^{a b}$ & $0.484^{\mathrm{c}}$ \\
\hline Hold water capacity $40 \%$ & $0.716^{\mathrm{a}}$ & $36.24^{\mathrm{a}}$ & $0.615^{b}$ \\
\hline Hold water capacity $40 \%+\operatorname{MLE}_{(30)}$ & $0.818^{\mathrm{a}}$ & $36.53^{\mathrm{a}}$ & $0.760^{\mathrm{a}}$ \\
\hline
\end{tabular}

Means with the same letters are not significantly different at $\mathrm{P} \leq 0.05$ by Duncan's multiple range test.

TABLE 6. Effect of foliar spraying of $\mathrm{MLE}_{(30)}$ on lipid peroxidation and osmolyte compounds (soluble sugars, proline and total phenol) in Glycine max (cv. Giza 111) plants grown under drought stress conditions.

\begin{tabular}{|c|c|c|c|c|}
\hline Treatments & $\begin{array}{l}\text { Lipid Peroxidation } \\
(\text { nmol MDA g-1 FW) }\end{array}$ & $\begin{array}{l}\text { Soluble Sugars } \\
\left(\mathrm{mg} \mathrm{g}^{-1} \mathrm{DW}\right)\end{array}$ & $\begin{array}{c}\text { Proline } \\
\left(\mu \mathrm{g} \mathrm{g}^{-1} \mathrm{FW}\right)\end{array}$ & $\begin{array}{c}\text { Total phenol } \\
\text { (mg tannic acid } \\
\left.\mathrm{g}^{-1} \mathrm{FW}\right)\end{array}$ \\
\hline Control & $35.22^{\mathrm{e}}$ & $65.5^{\mathrm{e}}$ & $20.2^{\mathrm{d}}$ & $2.5^{\mathrm{d}}$ \\
\hline $\operatorname{MLE}_{(30)}$ & $34.89^{\mathrm{e}}$ & $70.5^{\mathrm{d}}$ & $22.4^{\mathrm{d}}$ & $3.1^{\mathrm{cd}}$ \\
\hline Hold water capacity $60 \%$ & $51.16^{\mathrm{b}}$ & $79.9^{c}$ & $32.8^{\mathrm{c}}$ & $3.8^{\mathrm{cd}}$ \\
\hline Hold water capacity $60 \%+\operatorname{MLE}_{(30)}$ & $45.79^{\mathrm{d}}$ & $83.4^{\mathrm{bc}}$ & $36.2^{b}$ & $4.5^{\mathrm{bc}}$ \\
\hline Hold water capacity $40 \%$ & $56.42^{\mathrm{a}}$ & $86.6^{\mathrm{ab}}$ & $43.9^{\mathrm{a}}$ & $5.8^{\mathrm{b}}$ \\
\hline Hold water capacity $40 \%+$ MLE $_{(30)}$ & $47.64^{\mathrm{c}}$ & $87.6^{\mathrm{b}}$ & $46.6^{\mathrm{a}}$ & $7.8^{\mathrm{a}}$ \\
\hline
\end{tabular}

Means with the same letters are not significantly different at $\mathrm{P} \leq 0.05$ by Duncan's multiple range test.

The osmolyte compounds (total soluble sugars, proline and total phenol) accumulated under drought stresses may be contributed as scavenges of reactive oxygen species (ROS). As shown in Table 6, high significant increases were observed with increasing drought stress levels. In addition, application of $\mathrm{MLE}_{(30)}$ caused highly significant increases in soluble sugars, proline and total phenol as compared with control plants. A markedly increases in antioxidant compounds was observed under foliar spraying of drought stressed soybean plants with $\mathrm{MLE}_{(30)}$ as compared with control plants and the corresponding drought levels. The changes in the growth regulating hormones (auxins, gibberellins and abscisic acid) levels regulate the protective responses of plants against biotic and abiotic stresses. Results presented in Table 7 showed the changes in growth regulators extracted from soybean plants sprayed with $\operatorname{MLE}_{(30)}$ and stressed plants in the presence and absence of $\mathrm{MLE}_{30}$ 
TABLE 7. Effect of foliar spraying MLE $_{(30)}$ on phytohormone contents (mg/100g) and mineral contents (\%) in Glycine max (cv. Giza 111) plants grown under drought stress conditions

\begin{tabular}{|c|c|c|c|c|c|c|}
\hline \multirow[t]{2}{*}{ Treatments } & \multicolumn{3}{|c|}{$\begin{array}{l}\text { phytohormone contents } \\
\text { (mg/100g) }\end{array}$} & \multicolumn{3}{|c|}{ Chemical contents $(\%)$} \\
\hline & IAA & $\mathbf{G A}_{3}$ & ABA & $\mathbf{N}$ & $\mathbf{P}$ & $\mathbf{K}$ \\
\hline Control & $10.59^{c}$ & $13.52^{\mathrm{bc}}$ & $3.27^{\mathrm{c}}$ & $3.2^{\mathrm{c}}$ & $0.64^{\mathrm{c}}$ & $1.3^{\mathrm{b}}$ \\
\hline $\operatorname{MLE}_{(30)}$ & $12.65^{\mathrm{a}}$ & $16.01^{\mathrm{a}}$ & $2.07^{\mathrm{d}}$ & $5.1^{\mathrm{a}}$ & $0.80^{\mathrm{a}}$ & $1.4^{\mathrm{b}}$ \\
\hline Hold water capacity $60 \%$ & $8.69^{d}$ & $12.43^{\mathrm{c}}$ & $4.50^{\mathrm{b}}$ & $2.6^{\mathrm{d}}$ & $0.42^{\mathrm{e}}$ & $0.84^{\mathrm{c}}$ \\
\hline Hold water capacity $60 \%+\mathrm{MLE}_{(30)}$ & $11.82^{\mathrm{b}}$ & $14.01^{\mathrm{b}}$ & $3.97^{\mathrm{c}}$ & $4.3^{\mathrm{b}}$ & $0.69^{b}$ & $1.7^{\mathrm{a}}$ \\
\hline Hold water capacity $40 \%$ & $7.52^{\mathrm{e}}$ & $10.08^{\mathrm{d}}$ & $7.02^{\mathrm{a}}$ & $2.6^{\mathrm{d}}$ & $0.34^{\mathrm{f}}$ & $0.69^{\mathrm{c}}$ \\
\hline Hold water capacity $40 \%+$ MLE & $11.01^{\mathrm{b}}$ & $13.97^{\mathrm{b}}$ & $2.64^{\mathrm{d}}$ & $3.4^{\mathrm{c}}$ & $0.52^{\mathrm{d}}$ & $0.86^{\mathrm{c}}$ \\
\hline
\end{tabular}

Means with the same letters are not significantly different at $\mathrm{P} \leq 0.05$ by Duncan's multiple range test.

The obtained results showed that IAA and $\mathrm{GA}_{3}$ levels were reduced in soybean plants with increasing levels of drought stress $(60 \%$ and $40 \%$ hold water capacity) as compared with those of the control. In contrast and proportional to drought stress, ABA content was significantly enhanced in the stressed plants over control.The foliar application of $\mathrm{MLE}_{30}$ alone or in combination with drought stress caused highly significant increase in both IAA and $\mathrm{GA}_{3}$ contents. On the other hand, ABA content showed highly significant decrease as compared with control plants. From the results obtained in Table 7, it was revealed that a high significant decrease in nutrients content under drought levels was observed as compared with control plants. In contrast of this result, there were positive increases in the accumulation of $(\mathrm{N}, \mathrm{P}$ and $\mathrm{K}$ ) with spraying Moringa leaf extract. Uptake and accumulation of these mineral ions in soybean plants were significantly higher due to the enhancingeffect of Moringa leaf extract.

\section{Discussion}

Water soil deficit causes a directand observable reduction in plant growth of soybean plants. Drought caused significant reductions in the shoot and root lengths, fresh and dry weight of shoots and roots of stressed soybean cv. Giza 111 as compared with the control plant. These results are agreement with the results obtained by Assaha et al. (2016) who reported that water deficit markedly inhibited shoots and roots growth of huckleberry (Solanum scabrum Mill.) plant. The suppression of plant growth under drought stress might be attributed to the metabolic disorders induced by stress, generation of ROS that causes a reduction in division and elongation of cells, meristematic divisions, cell turgor, cell volume and eventually cell growth, decrease in photosynthetic capacity of plant leaves and/or blocking up the translocation vessels thus it hindering any movement of water or nutrients through it (Banon et al., 2006). On the other hand, foliar spray with Moringa oleifera leaf extract $\left(\mathrm{MLE}_{30}\right)$ in drought stressed soybean plants significantly improved plant growth parametersas well as physio-chemical attributes under the adverse conditions of water deficit. These results are in harmony with Ali et al. (2011) who reported that the plant growth parameters of Zea mays (shoot and root length, fresh and dry weights of shoots and roots) decreased significantly with increasing drought stress as compared with control plants. The observed slight reduction in growth could be attributed to its role as growth enhancer because its enriched with protein contents that essential for the formation of the protoplasm, vitamin $\mathrm{C}$, essential nutrients such as potassium, calcium and magnesium that act as good source of natural antioxidant compounds such as ascorbic acid, flavonoids, phenolics and carotenoids that make it excellent plant growth enhancer. Also, it has promoting hormones such as auxins and cytokinins (especially zeatin) that have growth promoting capabilities in enhancing the cell division, multiplication, enlargement and inducing chlorophyll biosynthesis.(Rady et al., 2015).

Chlorophylls content must be maintained under water stressed to support photosynthetic capacity in plants. In the present study, chlorophylls (chlorophyll a, b) carotenoids and total pigment contents are drastically reduced under drought stress as compared with control. These result is agree with Jomo et al. (2016) who found that, soil water deficit significantly reduced chlorophyll contents of amaranth species with increasing the level of drought stress. This reduction can be considered as a typical symptom of oxidative stress. This reduction may be

Egypt. J.Bot. 57, No.2 (2017) 
attributed to the photo-oxidation or chlorophyll degradation by the formation of proteolytic enzymes like chlorophyllase, deterioration in chloroplast, stomatal closure. On the other hand, a possible reduction in stomata conductance leading to a decreased photosynthetic level which is attributed to the inhibitory effect of decreased water content in leaves (Vurayai et al., 2011). Whilst MLE $_{30}$ foliar application improved these contents in Glycine max leaves. Azra et al. (2013) also found an increase in chlorophyll contents when MLE was applied to wheat plants under drought conditions. The foliar application of Moringa extract could stimulate the production of phyto-regulator cytokinins in plant or correlated with cytokinin levels (Zeatin) found in MLE which prevents leaf senescence and reduction in chlorophylls content. Moreover, Moringa leaves have high content of nutritional potentialities of different macro elements such as $\mathrm{Mg}$, a constituent of chlorophyll that would responsible for induction in the amounts of chlorophyll $a, b$ in Glycine max plants. Also, its appreciable contents of carotenoids ( $\alpha, \beta$ carotene, xanthin and lutein) that have potent antioxidant properties (Zaki \& Rady, 2015).

Many studies have indicated that, to avoid the damage caused by water deficit stress, plants have developed some non-enzymatic antioxidant substances that having low molecular weights and generated in the direct elimination of ROS during stress. Some of these substrates are ascorbic acid (AsA), $\alpha$-tocopherol and reduced glutathione (GSH). Drought stress exhibit significant increases in ascorbic acid, $\alpha$-tocopherol and glutathione in soybean plants (cv. Giza 111) as compared with control plant. These are in agreement with the result of Abdul Jaleel (2009) who reported high levels of ascorbic acid, tocopherol and glutathione contents in Withania somnifera plants under drought stress as compared with control plant.

Moreover, Hasanuzzaman \& Fujita (2011) stated that under drought stress rapeseed seedlings showed an enhancement in GSH content. Ascorbic acid acts as a powerful that can donate electrons to the enzymatic and non-enzymatic antioxidant systems leading to regulation of cell elongation, protection of proteins, lipids and thus protected against oxidative stress (Hasanuzzaman $\&$ Fujita, 2011). The induced levels of tocopherol under water deficit stress may be due to gene activities responsible for tochopherol synthesis. Glutathione (a substrate for GPX) has vital roles in some metabolic processes like cell division, activity of enzymes, biosynthesis of proteins and expression of genes. Moreover, itprotects cells from $\mathrm{H}_{2} \mathrm{O}_{2}$ toxicity, organic peroxides, proteins and membranes from oxidation (Mullineaux $\&$ Rausch, 2005). These increases in the levels of reduced glutathione in soybean plants under drought stress may be attributed to the induction in glutathione reductase (GR) activity as well as higher rate of GSH synthesis. On the other hand, spraying plants with $\mathrm{MLE}_{(30)}$ showed significant increase in GSH, ascorbic acid and $\alpha$ - tocopherol contents of soybean plants above that of the corresponding controls. Because of $\mathrm{MLE}_{(30)}$ is good source of nutrients, amino acids, phenolics, soluble sugars and some antioxidant such as free proline and ascorbate, all of this induced the content of ascorbic acid (ASA), $\alpha$-tocopherol and reduced glutathione contentsas antioxidants and consequently enable soybean plants to tolerate drought stress.

Moreover, the high significant increase in the activities of the antioxidant enzymes (GR, SOD and APX) was also reported in drought stressed soybean (cv. Giza 111) as compared with untreated plants. Similar results obtained by (Mirzaee et al., 2013) who revealed higher SOD and APX activities were observed in Canola (Brassica napus L.)subjected to drought stress. Moreover, Hasanuzzaman \& Fujita (2011) revealed that GR activity showed significant enhancement in rapeseed seedlings under mild drought stress, but not changed with severe drought.Application of Moringa leave extract caused high significant accumulation in SOD activity in soybean followed by GR and APX respectively. Zaki \& Rady (2015) reported that $\operatorname{MLE}_{(30)}$ application used as seed soaking or foliar spray were caused significant increase in the antioxidant enzymes glutathione reductase (GR), superoxide dismutase (SOD) and ascorbate peroxidase (APX) in common bean (Phaseolus vulgaris L.) plants.This extract of Moringacan prevent oxidative effect and afford significant protection against oxidative damage by modulate the gene expression responsible for metabolic processes and defense system. Lipid peroxidation (MDA content) is accumulated in leaves of soybean plants under drought stress. These results are in accordance with Saruhan et al. (2012) who found that drought increased the content of MDA in two maize genotypes. Lipid peroxidation is being a first indicator of stresses measured as malondialdehyde (MDA) content (Jain et al., 2001).It considered a major type of 
oxidative damage. It decreases cell membrane fluidity, ion channels, membrane proteins and enzyme activities and induce the leakiness of the cell membrane (Shehab et al., 2010). On the other hand, foliar spray with $\mathrm{MLE}_{30}$ extract significantly reduced MDA level in leaves of soybean plants when compared to drought stressed plants and control plants. Moringa olifera extract contains a significant level of calcium which can preventing injurious and leakage of membrane as well as stabilizing membrane structure under adverse drought conditions.

Soluble sugars and proline existence has a vital contribution for osmotic adjustment in plant cell (Hayashi et al., 1997), there were a significantly increased in both drought-stressed soybean plants and treated plants by $\mathrm{MLE}_{(30)}$ (Table 6). Stress caused a depletion of starch and accumulation of soluble sugars in plant leaves. These accumulated sugars act as osmolytes to maintain proteins, cell turgor and membrane stability from damage (Kaplan \& Guy, 2004).

On the other hand the accumulation of proline is considered one of the most frequent changes induced during stress damages. These results are in accordance with Abass \& Mohamed (2011) who showed that the drought condition caused significant increase in the soluble sugar and proline contents in shoot of common bean (Phaseolus vulgaris L.) plants. Proline and soluble sugar levels are significantly over those induced in soybean plants when leaves sprayed with $\mathrm{MLE}_{(30)}$ as compared with stressed plants and untreated plants. These results are in accordance with Foidl et al. (2001) who revealed that spraying of plant with Moringa extract caused induction in total soluble sugar contents. The accumulation of total sugars in soybean plants treated with $\mathrm{MLE}_{(30)}$ may be due to the high sugar content which makes it of great scientific and agricultural interest (Yameogo et al., 2011). Also, Rady et al. (2015) who detected that the integrated application of $\mathrm{MLE}_{(30)}$ improved the accumulation of antioxidant compounds in common bean plants via the increase in the contents of proline. In this respect, the protection effect of exogenous application of Moringa oleifera leaves extract $\left(\mathrm{MLE}_{30}\right)$ that containing mineral ions, ascorbates, cytokinins (zeatin) and phenolics (Azra, 2011) on soybean plants against drought stress is believed to be caused indirectly by proline accumulation that has a defensive roles in modulation of mitochondrial functions, maintaining cell water, ionic balance and thus plant development under drought stress conditions.

Phenols are one of the largest groups of plants secondary metabolite. They are significantly increased under water deficit conditions. They directly react with super-oxide anions and lipid peroxyl radicals that consequently reduce or breakdown the chain of lipid peroxidation (Rajanandh \& Kavitha, 2010). The present investigation showed a significant increase in phenols content under drought stress (Table 6), over the control plant. Application of $\mathrm{MLE}_{(30)}$ by a foliar spraying have more stimulatory effects on total phenolic levels in drought stressed soybean plants as compared with control and corresponding drought levels.

These results are in harmony with Basra et al. (2011) who reported that phenolic contents induced in maize seedlings when the seeds were treated with $\mathrm{MLE}_{30}$. This enhancement of phenolic contents due to MLE application might be attributed to its higher content of phenols. Plants under stress conditions revealed some modification such as higher or lower production of growth regulators (Mok \& Mok, 2001). This modification via phytohormone production levels which is influenced by the change of enzyme that participates in phytohormones synthesis or that involved in the degradation of xenobiotics (Vaseva-Gemisheva et al., 2005). On the other hand, the content of growth hormones (auxins and gibberellins) increased significantly in response to $\mathrm{MLE}_{30}$, while ABA levels decreased. These results are harmony with Abdalla (2013) who reported that treated rocket (Eruca vesicaria) plants with Moringa extract increased the levels of phytohormones (Table 7).

Inorganic ions such as nitrogen $(\mathrm{N})$, phosphorus $(\mathrm{P})$, potassium $(\mathrm{K})$ have important roles in plant mechanisms. The decline in soil water actually reduces nutrient ions uptake and nutrient transport in plants (Sardans \& Penuelas, 2012).The inhibition in nutrient uptake by plants under water stress (Table 7) is related to reduction in transpiration process, impaired active transport and membrane permeability (Tanguilig et al., 1987). Leaf extract of Moringa oleifera plants has been reported to be a rich source of many minerals such as $\mathrm{Ca}, \mathrm{P}, \mathrm{Na}, \mathrm{Mg}, \mathrm{K}, \mathrm{Fe}$ and others that can be valorized for nutrition balance in plants (Moyo et al., 2011). The uptake and accumulation of nutrients $\mathrm{N}, \mathrm{P}, \mathrm{K}$ in soybean plants were significantly induced due to the effect of the 
Moringa leaf extract fertilization. Sivakumar \& Ponnusami (2011) realized the increased uptake and accumulations of some nutritive elements as $\mathrm{N}, \mathrm{K}, \mathrm{Ca}, \mathrm{Mg}$ and $\mathrm{P}$ as well as $\mathrm{Fe}$ in roots and shoots of several plants by using Moringa leaf extract. MLE is supposed to accelerate the nutrient uptake and translocation through the soybean plant by increasing the root membranes permeability for electrolytes, preventing nutrients fixation and increasing its mobility in soil.

\section{Conclusion}

The present results suggest that Moringa leaf extract $\left(\mathrm{MLE}_{30}\right)$ could trigger the activation of physiological compounds persist in plants to alleviate the oxidative damage causing by drought, leading to improvements in physiological and biochemical aspects for the plant growth under drought conditions. Moringa leaves extracts can be used to alleviate the adverse effect of water deficit stress.

\section{References}

Abass, S.M. and Mohamed, H.I. (2011) Alleviation of adverse effects of drought stress on common bean (Phaseolus vulgaris L.) by exogenous application of hydrogen peroxide. Bangladesh Journal of Botany, 41(1), 75-83.

Abdalla, M.M. (2013) The potential of Moringa oleifera extract as a biostimulant in enhancing the growth, biochenmical and hormonal contents in rocket (Erucavesicaria subsp. sativa) plants. International Journal of Plant Physiology and Biochemistry, 5, 42-49.

Abdul Jaleel, C. (2009) Non-enzymatic antioxidant changes in Withania somnifera with varying drought stress levels. American-Eurasian Journal of Scientific Research, 4 (2), 64-67.

Ali, M.A, Abbas, A. Awan, S.I. Jabran, K. and Gardezi, S.D.A. (2011) Correlated response of various morpho-physiological characters with grain yield in sorghum landraces at different growth phases. The Journal of Animal and Plant Sciences, 21 (4), $671-679$.

AOAC (1995) "Official Methods of Analysis," $16^{\text {th }}$ ed, 8-9.

Assaha, D.V.M. Liu, L. Ueda, A. Nagaoka, T. and Saneoka, H. (2016) Effects of drought stress on growth, solute accumulation and membrane stability of leafy vegetable, huckleberry (Solanum scabrum Mill.) Journal of Environmental Biology, 37, 107-114.

Azra, Y. (2011) Exploring the potential of moringa (Moringa oleifera) leaf extract as a natural plant growth enhancer. $P h D$ Thesis, University of Agriculture, Faisalabad.

Azra, Y., Basra, S.M.A., Ahmad, R. and Wahid, A. (2012) Performance of late sown wheat in response to foliar application of Moringa oleifera Lam. leaf extract. Chilean Journal of Agricultural Research, 2, 92-97.

Azra, Y., Basra, S.M.A., Wahid, A., Farooq, M., Nouman, W., Rehman, H.U. and Hussain, N. (2013) Improving drought resistance in wheat (Triticum aestivum) by exogenous application of growth enhancers. International Journal of Agriculture and Biology, 15,1307-1312.

Banon, S.J., Ochoa, J. Franco, J.A., Alarcon, J.J. and Sanchez-Blanco, M.J. (2006) Hardening of oleander seedlings by deficit irrigation and low air humidity. Environmental and Experimental Botany, 56, 36-43.

Basra, S.M.A. Iftikhar, M.N. and Afzal, I. (2011) Potential of moringa (Moringa oleifera) leaf extract as priming agent for hybrid maize seeds. International Journal of Agriculture and Biology, 13, 1006-1010.

Bates, L.S. Waldren, R.P. and Teare, L.D. (1973) Rapid determination of free proline for water-stress studies. Plant and Soil, 39, 205-207.

Chen, J.X. and Wang, X.F. (2006) "Plant Physiology Experiment Instruction". Guangzhou: South China University of Technology Press.

El-Beltagi, H.S. and Mohamed, H.I. (2013) Alleviation of cadmium toxicity in Pisum sativum L. seedlings by calcium chloride. Notulae Botanicae Horti Agrobotanici Cluj-Napoca, 41(1), 157- 168.

El-Tayeb, M.A. (2006) Differential response of two Vicia faba cultivars to drought: growth, pigments, lipid peroxidation, organic solutes, catalase and peroxidase activity. Acta Agronomica Hungarica, 54, 25-37.

Foidl, N. Makkar, H.P.S. and Becker, K. (2001) The potential of Moringa oleifera for agricultural and industrial uses.In: Proceedings of the International Workshop "What development potential for Moringa products”, pp. 47--67. Dares-Salaam, Tanzania.

Hasanuzzaman, M. and Fujita, M. (2011) Selenium pretreatment upregulates the antioxidant defense and methylglyoxal detoxification system and confers enhanced tolerance to drought stress in rapeseed seedlings. Biological Trace Element Research, 143 (3), 1758-1776.

Hayashi, H. Mustardy, A.L. Deshnium, P., Ida, M. and Murata, N. (1997) Transformation of Arabidopsis thaliana with the codA gene for 
choline oxidase; accumulation of glycinebetaine and enhanced tolerance to salt and cold stress. The Plant Journal, 12, 133-142.

Heath, R.L. and Packer, L. (1968) Photoperoxidation in isolated chloroplasts. I. Kinetics and stoichiometry of fatty acid peroxidation. Archives of Biochemistry and Biophysics, 125 (1), 189-198.

Homme, P.M. Gonzalez, B. and Billard, J. (1992) Carbohydrate content, frutane and sucrose enzyme activities in roots, stubble and leaves of rye grass (Lolium perenne L.) as affected by source/link modification after cutting. J. Plant Physiology, 140, 282-291.

Humphries, E.C. (1956) Mineral components and ash analysis. In : Modern Methods of Plant Analysis"1: 468-502.

Jain, M., Mathur, G., Koul, S. and Sarin, N.B. (2001) Ameliorative effects of proline on salt stressinduced lipid peroxidation in cell lines of groundnut (Arachis hypogaea L.). Plant Cell Reports, 20, 463-468.

Jomo, M. Netondo, W. and Musyimi, M. (2016) Drought inhibition of chlorophyll content among seven Amaranthus species. International Journal of Advanced Research in Science, Engineering and Technology, 3 (2), 1362-1371.

Kaplan, F. and Guy, C.L. (2004) Beta-amylase induction and the protective role of maltose during temperature shock. Plant Physiology, 135,1674-1684.

Kim, D.O., Jeong, S.W. and Lee, C.Y. (2003) Antioxidant capacity of phenolic phytochemicals from various cultivars of plums. Food Chemistry, 81, 321-326.

Lichtenthaler, H.K. (1987) Chlorophylls and carotenoids: Pigments of photosynthetic biomembranes. Methods in Enzymology, 148, 350-382.

Mirzaee, M. Moieni, A. and Ghanati, F. (2013) Effects of drought stress on the lipid peroxidation and antioxidant enzymes activities in two canola (Brassica napus L.) cultivars. Journal of Agricultural Science and Technology, 15, 593-602.

Mok, D.W. and Mok, M.C. (2001) Cytokinin metabolism and action. Annual Review of Plant Physiology and Plant Molecular Biology, 52, 89-118.

Moyo, B., Masika, P.J., Hugo, A. and Muchenje, V. (2011) Nutritional characterization of Moringa (Moringa oleifera Lam.) leaves. African Journal of Biotechnology, 10, 12925-12933.

Mukherjee, S.P. and Choudhuri, M.A. (1983) Implications of water stress induced changes in the levels of endogenous ascorbic acid and hydrogen peroxide in Vigna seedlings. Plant Physiology, 58, 166-170.

Mullineaux, P.M. and Rausch, T. (2005) Glutathione, photosynthesis and the redox regulation of stressresponsive gene expression. Photosynthesis Research, 86, 459-474.

Nakano, Y. and Asada, K. (1987) Purification of ascorbate peroxidase in spinach chloroplasts: its inactivation in ascorbate-depleted medium and reactivation by monodehydroascorbate radical. Plant and Cell Physiology, 28, 131-140.

Paradiso, A. Berardino, R. de Pinto, M.C., Toppi, L.S., Storelli, M.M., Tommasi, F. and de Gara, L. (2008) Increase in ascorbate-glutathione metabolism as local and precocious systemic responses induced by cadmium in durum wheat plants. Plant and Cell Physiology, 49, 362- 374.

Philip, B, Bernard, L. and William, H. (1954) Vitamins and deficiency diseases, In, "Practical Physiological Chemistry," pp.1272-1274McGraw-Hill company, INC: New York, Toronto, London.

Rady, M.M. Mohamed, G.F. Abdalla, A.M. and Ahmed, Y.H.M. (2015) Integrated application of salicylic acid and Moringa oleifera leaf extract alleviates the salt-induced adverse effects in common bean plants. International Journal of Agricultural Technology, 11(7), 1595-1614.

Rajanandh, M.G. and Kavitha, J. (2010) Quantitative estimation of $\beta$-sitosterol, total phenolic and flavonoid compounds in the leaves of Moringa oleifera. International Journal PharmTech Research 2 (2),1409-1414.

Rohbakhsh, H. (2013)Alleviating adverse effects of water stress on growth and yield of forage sorghum by potassium application. Advances in Environmental Biology,7 (1), 40-46.

Sakthivelu, G., Akitha, Devil. M.K., Giridhar, P. Rajasekaran, T., Ravishankar, G.A., Nedev, T. and Kosturkova, G. (2008) Drought- induced alterations in growth, osmotic potential and in vitro regeneration of soybean cultivars. General and Applied Plant Physiology, 34 (1- 2), 103-112.

Sardans, J. and Penuelas, J. (2012) The role of plants in the effects of global change on nutrient availability and stoichiometry in the plant-soil system. Plant Physiology, 160,1741-1761.

Saruhan, N. Saglam,A. and Kadioglu,A. (2012) Salicylic acid pretreatment induces drought tolerance and delays leaf rolling by inducing antioxidant systems in maize genotypes. Acta Physiologiae Plantarum, 34, 97-106. 
Schaedle, M. and Bassham, J.A. (1977) Chloroplast glutathione reductase. Plant Physiology, 59, 1011-1012.

Shehab, G.G. Ahmed, O.K. and El-Beltagi, H.S. (2010) Effects of various chemical agents for alleviation of drought stress in rice plants (Oryza sativa L.). Notulae Botanicae Horti Agrobotanici ClujNapoca, 38 (1), 139-148.

Sivakumar, V. and Ponnusami, V. (2011) Influence of spacing and organics on plant nutrient uptake of Solanum nigrum. Agricultural Science Digest, 11 (1), 431- 434 .

Tanguilig, V.C., Yambao, E.B., Toole, J.C. and Dedatta, S.K. (1987) Water-stress effects on leaf elongation, leaf water potential, transpiration and nutrient-uptake of rice, maize and soybean. Plant and Soil, 103, 155-168.

Ünyayar, S., Topcuoglufi, F. and Ünyayar, A. (1996) A modified method for extraction and identification of Indole-3-acetic acid (IAA), gibberellic acid $\left(\mathrm{GA}_{3}\right)$, abscisic acid (ABA) and zeatin produced by Phanerochaete chrysosporium ME446. Bulgarian Journal of Plant Physiology, 22, 105-110.

Vaseva-Gemisheva, I. Lee, D. and Karanov, E. (2005) Response of Pisum sativum cytokinin oxidase/ dehydrogenase expression and specific activity to drought stress and herbicide treatments.
Plant Growth Regulation, 46,199-208.

Vurayai, R., Emongor, V. and Moseki, B. (2011) Effect of water stress imposed at different growth and development stages on morphological traits and yield of bambara groundnuts (Vigna subterranean L. Verde). American Journal of Plant Physiology, 6 (1), 17-27.

Yameogo, C.W., Bengaly, M.D., Savadogo, A., Nikiema, P.A. and Traore, S.A. (2011) Determination of chemical composition and nutritional values of Moringa oleifera leaves. Pakistan Journal of Nutrition, 10 (3), 264-268.

Yemm, E.W. and Willis, A.J. (1956) The respiration of barley plants. IX. The metabolism of roots during the assimilation of nitrogen. - New Physiologist, 55, 229-252.

Yu, C.W., Murphy, T.M. and Lin, C.H. (2003) Hydrogen peroxide-induced chilling tolerance in mung beans mediated through ABA-independent glutathione accumulation. Functional Plant Biology, 30,955 -963.

Zaki, S.S. and Rady, M.M. (2015) Moringa oleifera leaf extract improves growth, physiochemical attributes, antioxidant defense system and yields of salt-stressed Phaseolus vulgaris L. plants.International Journal of ChemTech Research, 8 (11), 120-134.

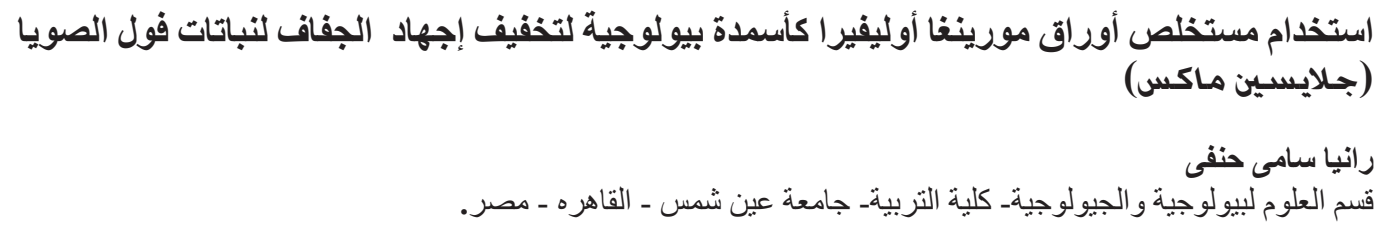

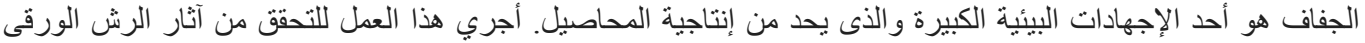

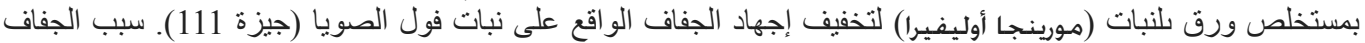

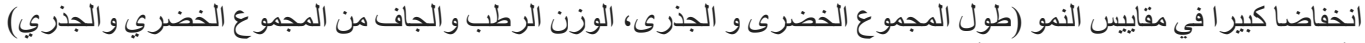

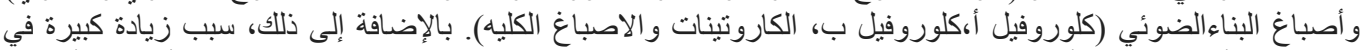

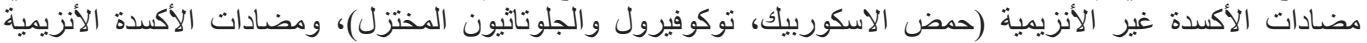

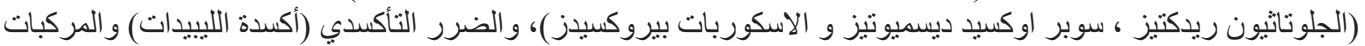

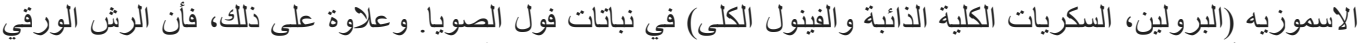

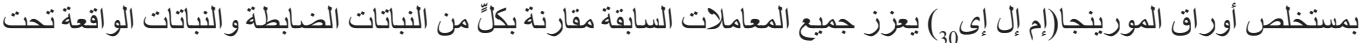

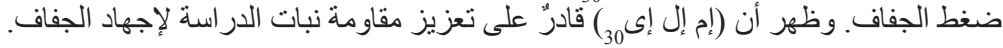

